\title{
Peranan RRI Medan dalam Meningkatkan Kesadaran Memilih Masyarakat Pada Pemilukada 2018
}

\author{
Syawilda, Nurhasanah Nasution ${ }^{*}$ \\ Program Studi Ilmu Komunikasi Universitas Muhammadiyah Sumatera Utara, Indonesia \\ Koresponden: syawildafebriyanibey@gmail.com
}

\begin{abstract}
ABSTRAK
Kajian dalam penelitian ini bertujuan untuk mengetahui peranan lembaga penyiaran publik RRI Medan dalam meningkatkan kesadaran memilih masyarakat pada Pemilukada 2018 dengan menggunakan metode deskriptif-kualitatif. Teknik pengumpulan data melalui wawancara. Hasil penelitian ini menunjukkan bahwa RRI Medan berperan terhadap Pemilukada dalam meningkatkan kesadaran memilih masyarakat dalam menyampaikan informasi, pendidikan, kontrol sosial, menghubungkan masyarakat dan membentuk pendapat umum. Namun kesadaran memilih masyarakat tidak bisa disamaratakan karena ada faktor-faktor pendukung untuk menumbuhkan minat yaitu jenis kultur politik dimana individu itu tumbuh darinya atau kepribadian politik yang terbentuk darinya, berbagai revolusi dari perubahan budaya yang terjadi dimasyarakat, berbagai kemampuan dan kecakapan khusus yang dimiliki individu, juga tingkat pendidikannya.
\end{abstract}

Kata Kunci : RRI, Pemilukada, Agenda Setting.

\begin{abstract}
The presence of public broadcasting institutions is important because usually commercial broadcasting institutions before the local election have failed to become agents of democracy to be neutral and only serve the interests of dominant rulers or a handful of elites. This study aims to determine the role of RRI Medan public broadcasting institutions in 2018 local elections simultaneously in raising awareness of voting for the public and using agenda setting theory by using descriptive qualitative research. With primary data researchers get from interviews. The results of this study indicate that RRI Medan has a role in election in increasing awareness of choosing the community in conveying information, education, social control, connecting people and forming public opinion. But the awareness of choosing society cannot be generalized because there are supporting factors to foster interest, namely the type of political culture in which the individual grows from it or the personality
\end{abstract}

Keywords : RRI, Election, Agenda Setting.

\section{Pendahuluan}

Kehadiran lembaga penyiaran publik sebagai penyalur kebebasan berekspresi dan mengetahui informasi yang sehat seharusnya dapat menjadi media utama masyarakat dalam memenuhi kebutuhan informasi. Lembaga penyiaran publik adalah lembaga penyiaran yang berbentuk badan hukum didirikan oleh negara, bersifat independent, netral, tidak komersial dan berfungsi memberikan layanan untuk kepentingan masyarakat.

Lembaga penyiaran publik yang dimiliki republik Indonesia sebagaimana tercantum dalam Undang-Uundang Nomor 32 Tahun 2002 Tentang Penyiaran pasal 14 ayat (2) yakni "lembaga penyiaran publik sebagaimana dimaksud dalam ayat (1) terdiri atas Radio Republik Indonesia dan Televisi Republik Indonesia yang stasiun pusat 
penyiarannya berada di ibukota negara republik Indonesia".

Penyiaran publik yang independent, netral dan tidak komersial yang berfungsi memberikan pelayanan siaran informasi, pendidikan, hiburan yang sehat, kontrol sosial, serta menjaga citra positif bangsa di dunia internasional. Besarnya tugas dan fungsi RRI yang diberikan oleh negara yakni melalui UU nomor 32 tahun 2002 tentang penyiaran, peraturan pemerintah nomor 11 tahun 2005 serta peraturan pemerintah nomor 12 tahun 2005 tentang lembaga penyiaran publik, RRI dikukuhkan sebagai satu-satunya lembaga penyiaran yang dapat berjaringan secara nasional dan dapat bekerja sama dalam siaran dengan lembaga penyiaran asing.

Lasswell 1946 menguraikan fungsi sosial media penyiaran publik yang cukup signifikan dalam (Mufid, 2005: 79), yaitu sebagai berikut :

a. Pengawas sosial (social surveillance), yaitu merujuk pada upaya penyebaran informasi dan interpretasi yang obyektif mengenai berbagai peristiwa yang terjadi di dalam dan di luar lingkungan sosial dengan tujuan kontrol sosial agar tidak terjadi hal-hal yang tidak diinginkan.

b. Korelasi sosial (social correlation), merujuk pada upaya pemberian interpretasi dan informasi yang menghubungkan satu kelompok sosial dengan kelompok sosial lainnya atau antara satu pandangan dengan pandangan lainnya dengan tujuan mencapai konsensus.

c. Sosialisasi (socialization), merujuk pada upaya pewarisan nilai-nilai dari satu generasi kegenerasi lainnya, atau dari satu kelompok ke kelompok lainnya.

Untuk menjangkau semua elemen masyarakat dalam menyampaikan informasi, RRI juga menyebar di seluruh Indonesia bahkan sampai ke pelosok negri untuk memberikan sabuk pengaman informasi di daerah perbatasan. Salah satunya yakni RRI Medan, RRI Medan hadir untuk memberikan ruang publik kepada masyarakat Medan. Ruang publik yang dimaksud adalah bahwa publik terbuka bukan hanya dalam mengisi muatan siaran RRI tetapi juga terbuka untuk jabatan-jabatan di jajaran dewan pengawas dan direksi, memberikan kebebasan berekspresi dan memperoleh informasi yang sehat dan independent.

Sesuai dengan selogan RRI "sekali di udara tetap di udara" RRI tetap eksis ditengah sengitnya persaingan dengan media massa mainstream yang menyajikan variasi program dan mengikuti selera pasar untuk menarik pendengar. Namun demikian RRI tetap konsisten kepada pendirian, memberi kebebasan kepada pengelola lembaga penyiaran publik untuk mebuat program-program sesuai tuntutan kreativitas, dan juga tidak lupa akan tugasnya sebagai lembaga publik.

Dewasa ini tidak sedikit masyarakat dibuat bingung oleh media yang hanya mementingkan kelompoknya saja sehingga untuk mencari informasi masyarakat harus teliti untuk menyaring informasi tersebut. Akibat dari kepentingan media dan sekelompok elit tersebut banyak masyarakat yang menganggap ikut kedalam pesta demokrasi dan mengkritisi segala bentuk permasalahan di negri ini adalah hal yang siasia di tambah dengan kondisi pemerintahan yang dianggap kurang memeperhatikan rakyat.

Maka dari itu masyarakat saat ini sudah harus memiliki kesadaran politik. Menurut Surbakti (2007) kesadaran politik adalah kesadaran akan hak dan kewajiban sebagai warga negara. Hal ini menyangkut pengetahuan seseoarang tentang lingkungan masyarakat dan politik dan menyangkut minat dan perhatian seseorang terhadap lingkungan masyarakat dan politik tempat ia hidup.

Lembaga penyiaran publik RRI Medan yang independen diperlukan sebagai 
forum pendidikan politik dan ruang kampanye yang setara dan murah bagi semua kandidat, sehingga dapat mengurangi beban finansial kampanye namun semata-mata bukan hanya untuk itu, RRI Medan juga diharapkan menjadi penetralisir ditengah media yang memiliki kepentingannya sendiri. Dengan keberadaan RRI Medan diharapkan mampu menjadi kontrol sosial di masyarakat, dan menjadi gambaran serta sumber informasi untuk masyarakat dalam menentukan pilihannya dan berpartisipasi kedalam pesta demokrasi.

Pemilihan umum Kepala Daerah dan Wakil Kepala Daerah (Pemilukada) merupakan instrumen yang sangat penting dalam penyelenggaraan Pemerintahan Daerah berdasarkan prinsip demokrasi di daerah, karena di sinilah wujud bahwa rakyat sebagai pemegang kedaulatan menentukan kebijakan kenegaraan. Mengandung arti bahwa kekuasaan tertinggi untuk mengatur pemerintahan Negara ada pada rakyat. Melalui Pemilukada, rakyat dapat memilih siapa yang menjadi pemimpin dan wakilnya dalam proses penyaluran aspirasi, yang selanjutnya menentukan arah masa depan sebuah negara (Yusdianto, 2010:44).

Penyelenggara pemilihan yakni KPU dan ditingkat daerah adalah KPUD dalam mensosialisasikan Pemilukada dan meningkatkan partisipasi politik masyarakat sudah sepantasnya melibatkan organisasi pemantau pemilihan kepala daerah atau pemilihan umum dan stakeholder yang satu tujuan, tapi dengan melibatkan organisasi tersebut saja tidak cukup maka media massa baik itu media elektronik, cetak dan online diperlukan dalam hal ini untuk menjadi perpanjang tangan mereka untuk meginformasikan dalam rangka menyukseskan pemilihan. RRI Medan sebagai media massa sekaligus lembaga publik memiliki kekuatan raksasa yang sangat diperhitungkan dalam konteks penyeberan informasi.

Angka GOLPUT yang tinggi di kota medan menjadi gambaran kurangnya minat masyarakat untuk terlibat dalam proses pemilihan, hal ini pula menjadi tugas bersama yang harus di tuntaskan untuk menjadikan kota medan menjadi kota yang demokratis dan berpartisipasi aktif. Media massa dapat menyampaikan pesan kepada khalayak ramai yang heterogen dan tersebar luas secara serentak dan merata.

Hal tersebut memungkinkan terciptanya keefektifan komunikasi untuk menyampaikan pesan. Pesan yang dikemas sedemikian rupa dapat mempersuasi masyarakat yang menerima pesan tersebut, hal ini dapat digunakan lembaga penyiaran publik radio republik Indonesia kota Medan demi menekan angka GOLPUT sebagai alat untuk memberikan informasi yang sehat, pendidikan serta menumbuhkan rasa kepercayaan untuk mendorong masyarakat memberikan suara pada Pemilukada serentak 2018.

\section{Kerangka Teori}

Perasaan sangat memegang peranan penting dalam mempertajam perbedaan-perbedaan tersebut sedemikian rupa, sehingga masing-masing pihak berusaha untuk saling meghancurkan. Perasaan ini biasanya terwujud dalam perasaan amarah dan rasa benci yang menyebabkan dorongan untuk ingin melukai atau menyerang pihak lain, atau untuk menekan atau menghancurkan individu atau kelompok yang menjadi lawan. Pertentangan atau konflik adalah suatu proses dimana individu atau kelompok berusaha untuk memenuhi tujuannya dengan jalan menantang pihak lawan yang disertai dengan ancaman atau kekerasan (Soekanto, 1990: 119). Suatu konflik yang terjadi antar kelompok menjadi tidak sehat apabila masing-masing pihak di dalam mencari pemecahanya tidak lagi bersifat rasional tapi lebih bersifat emosional. Akibatnya yang terjadi adalah seperti tawuran, penjarahan, perusakan rumah warga, perkelahian antar kelompok di dalam masyarakat. Kekerasan sudah dijadikan sebagai media penyelesaian 
masalah.

Walter Lipmann pernah mengutarakan pernyataan bahwa media berperan sebagai mediator antara " the world outside and pictures in our heads." Mc Combo dan Shaw sependapat dengan Lipmann. Menurut mereka, ada korelasi yang kuat dan signifikan antara apa-apa yang diagendakan oleh media massa dan apa-apa yang menjadi agenda publik (Tamburaka, 2012:22).

Maxwell McCombs dan Donald L. Shaw adalah orang yang pertama kali memperkenalkan teori agenda setting ini. Ketika diadakan penelitian tentang pemilihan presiden Amerika Serikat pada tahun 1968 ditemukan hubungan yang tinggi antara penekanan berita dengan bagaimana berita itu dinilai tingkatannya oleh pemilih. Secara singkat teori penyusunan agenda ini mengatakan media (khususunya media berita) tidak selalu berhasil memberitahu apa yang kita pikir, tetapi media tersebut benar-benar berhasil memberitahu kita berpikir tentang apa. Dengan kata lain media massa mengarahkan kita pada apa yang harus kita lakukan. Media memberikan agenda-agenda melalui pemberitaannya, sedangkan masyarakat akan mengikutinya. Media mengatakan pada kita apa yang penting dan apa yang tidak penting. Media pun mengatur apa yang harus kita lihat, tokoh siapa yang harus kita dukung (Nuruddin, 2007:195-196).

Menurut pendapat Kriyantono (2006: 220-223). Teori agenda setting mempunyai kesamaan dengan teori peluru yang menganggap media mempunyai kekutan mempengaruhi khalayak. Bedanya, teori peluru memfokuskan pada sikap (afektif), pendapat atau bahkan perilaku. Agenda setting memfokuskan pada kesadaran dan pengetahuan (kognitif).

Agenda media akan menjadi agenda masyarakatnya dan agenda media juga bisa sengaja dimunculkan untuk dijadikan topik yang ramai dibincangkan oleh masyarakat oleh karena itu agenda setting menekankan adanya hubungan positif antara penilaian yang diberikan media pada suatu persoalan dengan perhatian yang diberikan khalayak pada persoalan tersebut. Sementara itu Stephen W. Littlejohn pernah mengatakan, agenda setting ini beroperasi dalam tiga bagian sebagai berikut:

1. Agenda media itu sendiri harus diformat. Proses ini akan memunculkan masalah bagaimana agenda media itu terjadi pada waktu pertama kali.

2. Agenda media dalam banyak hal memengaruhi atau berinteraksi dengan agenda publik atau kepentingan isu tertentu bagi publik. Pernyataan ini memunculkan pertanyaan, seberapa besar kekuatan media mampu mengaruhi agenda publik dan bagaimana publik itu melakukannya.

3. Agenda publik memengaruhi atau berinteraksi ke dalam agenda kebijakan. Agenda kebijakan adalah pembuatan kebijakan publik yang dianggap penting bagi individu.

Dengan demikian, agenda setting ini memprediksikan bahwa agenda media memengaruhi agenda publik, sementara agenda publik sendiri akhirnya memengaruhi agenda kebijakan. Untuk memperjelas tiga agenda (agenda media, agenda khalayak dan agenda kebijakan) dalam teori agenda setting ini, ada beberapa dimendi yang berkaitan seperti yang dikekukakan oleh Mannheim sebagai berikut (Nuruddin, 2007:198-199):

1. Agenda media terdiri dari dimensi-dimensi berikut.

a.Visibility (visibilitas) yakni jumlah dan tingkat menonjolnya berita.

b. Audience salience (tingkat menonjol bagi khalayak) yakni relevansi isi berita dengan kebutuhan khalayak.

c.Valence (valensi) yakni menyenangkan atau tidak menyenangkan cara 
pemberitaan bagi siatu peristiwa.

2. Agenda khalayak, terdiri dari dimensi-dimensi berikut.

a.Familiarity (keakraban) yakni derajat kesadaran khalayak akan topik tertentu.

b. Personal salience (penonjolan pribadi) yakni relevansi kepentingan individu dengan ciri pribadi.

c.Favirability (kesenangan) yakni pertimbangan senang atau tidak senang akan topik berita.

3. Agenda kebijakan terdiri dari dimensi-dimensi berikut.

a.Support (dukungan) yakni kegiatan menyenangkan bagi posisi suatu berita tertentu.

b. Likelihood of actiun (kemungkinan kegiatan) yakni kemungkinan pemerintah melaksanakan apa yang diibaratkan.

c.Freedom of action (kebebasan bertindak) yakni nilai kegiatan yang mungkin dilakukan pemerintah.

Penyusunan agenda setting menjelaskan tiga proses. Pertama, berita diseleksi, diolah dan disajikan atau dikenal dengan proses gatekeeping. Kedua, kemudian menghasilkan agenda media. Ketiga, bagaimana agenda media mempengaruhi pendapat publik tentang isu yang ditonjolkan. Bagian paling penting dari proses tersebut adalah bagaimana menyusun dan menghasilkan agenda isu yang paling penting hingga yang paling tidak penting di mata publik. Ini yang disebut dengan agenda setting dari termuatnya isu-isu oleh media massa. Hasil dari seleksi dalam arus berita, publik menerima petunjuk dari apa yang penting dalam media kemudian publik memasukkan hal-hal tersebut ke dalam agenda kepentingan mereka pada saat itu.

\section{Metode}

Metode yang akan digunakan dalam penelitian ini adalah deskriptif kualitatif. Menurut Basrowi \& Suwandi (2008: 48) mengemukakan bahwa penelitian kualitatif antara lain bersifat deksriptif, data yang dikumpulkan adalah berupa kata-kata, gambar, dan bukan angka-angka.

Sampel dalam penelitian kualitatif bukan dinamakan responden, tetapi sebagai narasumber, atau partisipan, informan, teman dan guru dalam penelitian. Sampel dalam penelitian kualitatif juga bukan disebut sampel statistik, tetapi sampel teoritis karena tujuan penelitian kualitatif adalah untuk menghasilkan teori (Moleong, 2005:298).

Dalam penelitian ini digunakan teknik snowball sampling, teknik ini dipilih karena peneliti memilih informan berdasarkan tujuan dan pertimbangan tertentu, dan dengan menentukan kriteria-kriteria tertentu pada informan. Penelitian ini menggunakan beberapa teknik pengumpulan data, dengan tujuan supaya data-data yang dikumpulkan relevan dan sesuai dengan permasalahan yang dianngkat oleh peneliti. Adapun teknik pengumpulan data yang digunakan adalah: observasi, wawancara dan dokumentasi.

Teknik analisa data yang digunakan dalam penelitian yakni: reduksi data, penyajian data, dan verifikasi (Martono: 2015). Dan Lokasi penelitian bertempat di Radio Republik Indonesia Medan yang beralamat di Jl. Gatot Subroto No. 214 Medan, Sumatera Utara. Sedangkan waktu dalam penelititan ini berlangsung dibulan maret 2018.

\section{Hasil dan Pembahasan}

Peran lembaga penyiaran publik RRI Medan terhadap Pemilukada dalam 
meningkatkan minat memilih masyarakat yaitu memberikan informasi, memberikan pendidikan, sebagai kontrol sosial, menghubungkan masyarakat dan membentuk pendapat umum. sebagai lembaga penyiaran publik, RRI Medan telah menjalankan tugasnya dengan membuat program yang diharapkan dapat meningkatkan jumlah partisipasi memilih masyarkat.

Dikaitkan dengan teori agenda setting yang peneliti gunakan, dalam hasil pengamatan dan wawancara peneliti RRI Medan membuat agenda yang diharapkan dapat menjadi agenda masyarakat dan menjadi penting bagi masyarakat dan menghasilkan suatu tindak perilaku. Teori ini mengatakan bahwa jika sebuah media memberi tekanan pada suatu peristiwa, maka media tersebut akan memengaruhi khalayak untuk menganggap peristiwa tersebut sebagai sebuah peristiwa yang penting. Asumsi dasar di dalam teori ini adalah apa yang dianggap penting oleh media massa tersebut, maka juga akan dianggap penting oleh khalayak.

Agenda masyarakat akan diketahui dengan menanyakan kepada anggota masyarakat apa yang mereka pikirkan, apa yang mereka bicarakan dengan orang lain, atau apa yang mereka anggap sebagai masalah yang tengah menarik perhatian masyarakat (community salience).

Namun kesadaran memilih masyarakat tidak semuanya memiliki tingkat ketertarikan yang sama. Kesadaran memilih dan rasa keingintahuan juga di latar belakangi oleh faktor-faktor yaitu latar belakang pendidikan, lingkungan dimana individu itu bersosialisasi atau berkembang, pengetahuan yang dimiliki.

Faktor-faktor tersebut sangat mempengaruhi dalam meningkatkan kesadaran atau minat memilih masyarakat. Adapun indikator yang dapat dijadikan rujukan bahwa seseorang sudah menaruh minat atau perhatian terhadap suatu hal adalah sebagai berikut:

a. Kesadaran akan hak dan kewajiban sebagai warga negara

b. Kesadaran perlunya pemerintah yang legitimate/sah

c. Kesadaran perlunya mengikuti perkembangan informasi politik

d. Kesadaran perlunya mengikuti kegiatan politik.

Maka dari itu RRI berupaya dalam menjalankan perannya dalam meningkatkan minat ataupun partisipasi masyarakat dengan melakukan berbagai upaya memberikan tekanan kepada topik seputar Pemilukada agar menjadi agenda masyarakat dengan membuat berbagai program seperti Daerah Memilih dan pemberitaan secara berkelanjutan agar mendapatkan perhatian masyarakat khususnya pendengar RRI Medan.

\section{Kesimpulan}

RRI Medan sudah berperan aktif sebagai penyampai informasi bagi masyarakat . Hal ini dapat dibuktikan dengan agenda dan program yang telah dirancang oleh RRI Medan. Tingginya rating bebarapa program RRI seperti opini publik dan dialog interaktif juga sebagai pertanda bahwa masyarakat banyak menikmati program di RRI Medan. Adapun tingginya rating tersebut selain karena program yang dikemas oleh RRI sangat menarik minat masyarakat hal ini juga dipengaruhi hal lainnya yaitu RRI Medan sebagai lembaga penyiaran publik memberikan informasi yang sehat, netral, dan independent sehingga masyarakat tidak meragukan kebenaran informasi dari RRI.

Memberikan pendidikan serta kontrol sosial dengan memberikan kesempatan yang sama bagi setiap kandidat kepala daerah yang bertarung dalam Pemilukada serentak 2018 untuk berkampanye dan tanpa memihak. Selain itu RRI juga memberikan 
masyarakat untuk dapat berdiskusi dan menyampaikan aspirasinya kepada narasumber yang sedang diundang sehingga RRI berperan menghubungkan masyarakat dengan pemerintah maupun sebaliknya.

Dalam meningkatkan kesadaran memilih masyarakat RRI menjadikan peristiwa pada pemilihan kepala daerah 2015 lalu sebagai tolak ukur untuk lebih memberikan informasi yang berkualitas dan menggerakkan kesadaran masyarakat. Hal tersebut dibuktikan dengan adanya evaluasi dan perbaikan program dan penganggendaan yang tersistematis sehingga agenda media massa diharapkan menjadi agenda masyarakat.

Bagi RRI Medan diharapkan memberikan variasi siaran yang beragam dan memberi ketertarikan kepada masyarakat. Kegiatan off air yang dilakukan seharusnya dapat ditingkatkan kuantitasnya agar masyarakat mengetahui bahwa RRI masih setia menemani masyarakat di tengah media massa yang mempunyai kepentingan masingmasing. Tidak hanya untuk kalangan budayawan dan orang tua tapi diharapkan juga diperuntukkan untuk kaum muda dan akademisi.

Sumber daya manusia juga menjadi penting untuk meningkatkan kualitas di RRI Medan diharapkan RRI Medan juga menerima SDM yang memiliki jiwa yang aktif serta kreatif agar memiliki ide-ide yang baru tanpa menghilangkan ideologi dan ciri khas RRI.

Bagi masyarakat untuk mendapatkan suatu informasi seharusnya kita tidak bisa hanya menjadikan satu media sebagai refrensi, namun penting memiliki kepercayaan kepada suatu media yang bersifat independent dan tidak hanya mementingkan suatu kelompok saja.

\section{Daftar Pustaka}

Basrowi, Suwandi. (2008). Memahami Penelitian Kualitatif. Jakarta: Rineka Cipta. Kriyantono, Rachmat. (2006), Teknik Praktis Riset Komunikasi, Surabaya: Kencana Prenada Media Group.

Martono, Nanang. (2015). Metode Penelitian Sosial: Konsep-Konsep Kunci. Jakarta: RajaGrafindo Persada.

Moleong, Lexy. (2005). Metode Penelitian Kualitatif. Jakarta: RajaGrafindo Persada. Mufid, Muhamma., (2005). Komunikasi Dan Regulasi Penyiaran. Jakarta: Kencana. Nuruddin. (2007). Pengantar Komunikasi Massa, Jakarta: PT. RajaGrafindo Indonesia. Surbakti, Ramlan. (2007). Memahami Ilmu Politik, Jakarta: Grasindo.

Tamburaka, Apriadi, (2012). Agenda Setting Media Massa, Jakarta: PT. RajaGrafindo Indonesia. 